\title{
Identification of Communcation Needs of Extension Agents in Ondo State Nigeria.
}

\author{
${ }^{1}$ Okoedo-Okojie D.U.and E.W Edobor ${ }^{2}$ \\ Department of Agricultural Economics and Extension Services, Faculty of Agriculture, University of Benin \\ P.M.B.1154 Benin City, Nigeria.
}

\begin{abstract}
The study identified the communication needs of extensions agents in Ondo State, Nigeria. Specifically the study examined personal characteristics of extension agents, their perceived communication needs, frequency of training and factors that contract these needs. Data were obtained from 80 respondents randomly selected in a 2-stage sampling technique and were analysed using frequency counts, means, percentages and PPMC. Results show that majority (52.5\%) and (58.8\%) of the respondents were between 41 and 50years, and females respectively with mean working experience of 10 years. Respondents training was most frequent on internet websites $(M=3.64)$ which was also their most perceived communication need $(M=2.81)$. Inadequate funds for proper communication $(M=4.33)$ was a major constraint. Regular in-service training of extension agents on extension teaching methods/process and conflict management was recommended.

Keywords: Identification, communication needs, extension agents
\end{abstract}

\section{Introduction}

Agricultural extension is an essential institutional component in the process of agricultural development which aims at providing farmers with necessary education, skills and technical information to enable them make effective farm management decisions to enhance their daily practices. Swanson (1984) described it as "an educational process, which has goals of communication of useful information to people, then helping them to learn how to use it to build a better life for themselves, their families, and their communities." The role of extension agents in bringing agricultural innovation to farmers as well as farmers' problem to scientists, by implication, makes communication needs of extension agents an issue of research. This was why the Federal Government of Nigeria in collaboration with the World Bank initiated Agricultural Development Programmes (ADPs) across the country. The ADPs thus become the extension arms of state ministries of agriculture and rely on extension agents (EA's) as a vehicle for achieving its objectives (Fatunbi 1994). The needs of extension agents within an ADP as an organization include: adequate role clarity; favourable perception routine duties; and effective time budgeting. Therefore, the effect of extension work depends to a large extent on the professional competence of extension agents. The need, burden and development of agriculture depend on agricultural extension service.

Agriculture with its positive impact on the Nigerian populace is faced with myriad of problems among which is low utilization of technologies. The non-use of technologies by the farmers may be ascribed to inadequacy of information, which is a pointer to the new technologies resulting from poor communication approaches. The purpose of communication is to bring about changes in attitude, knowledge and skills of the receivers. Johnson and Johnson (1991) stated that effective communication is a prerequisite to every aspect of group functioning. The major challenge of agriculture in this new millennium is how to cope with information and trends in technology transfer. Aboyade (1987) observed that farmers were neither adequately nor appropriately informed about innovations meant to be applied by them to achieve improved agricultural productivity and enhanced standards of living. This inability to adequately inform the farmer could be blamed on inefficient communication from extension agents.

Agriculture is perhaps the most interdisciplinary of all spheres of human activities drawing as it were, from Biology, Medicine, Chemistry, Soil science, various branches of Engineering climatology, food technology, environment science, economics management and host of their field. This interdisciplinary attribute brings with it some special problem in the provision of effective library and information services. Yet extension agents are expected to meet both farmer and researcher needs by communicating valuable information to them.

Omokhudu (1999) identified ADPs and research institutes as neighbours, as major sources of information to farmers on farming technologies and noted that though valuable research results have been obtained from most of the agricultural research institutions in Nigeria, most of these improved agricultural practice do not get to the farmers thus creating a wide gap between research and utilization of the research results. To bridge this gap between the farmer and researchers effective communication is essential. Different researchers in their studies identified sources frequently and regularly used by farmers in obtaining agricultural information on new farming practices and they include extension officers, radio and fellow farmers. Ideally 
extension workers should be linked to the transfer process. They need the technical skills in using information, understanding scientific recommendations, interpreting and simplifying knowledge in addition to skills in communication. If farmers are going to accept new technologies, it means that recommendation must be specific to their farming requirement.

The Ondo State ADP was established by Edict on 3rd February 1976 of the former Western State of Nigeria as one of the Multi-State Agricultural Development Projects MSAPP-1 with the objectives of Facilitating incremental food production of small-scale farmers and promoting infrastructural development of rural areas in term of rural road and water supplies, Federal Ministry of Agriculture and Rural Development (FMARD, 1976). Major activities of extension agents in Ondo state ADP include: teaching of production recommendation to farmers, and participating in adhoc duties such as sensitization of farmers on agricultural policies, agricultural campaign, health campaigns, linkage of farmers to credit facilities, and sourcing of credit. They are also known to assist subject matter specialist (SMS) in research and are also involved in conducting surveys.

The evolution of extension services began as sufficient research knowledge was accumulated to permit effective production-enhancing educational programmes to keep framers abreast of the new technologies (Swanson, 1984). This information is used by the management of the extension organization to instruct extension agents what they should tell farmers in the expectation that such messages will bring about changes in farm management (Van den Ban and Hawkins, 1998). There has been realization on the part of government that the accomplishment of wide-range agricultural objectives would dependent to an appreciable degree, on the systemic delivery of research-based technical information to farmers through extension (Lukhele, 1994).

The World Bank (1990) recognizes the challenges for extension organizations based on the complex processes involved in changing human behaviour through communication. It was this realization that led to the development of the concept of Agricultural Knowledge Information System (AKIS). Without a continual flow of new technologies and tested recommendations from research, extension can run out of technology to extend; and without close links with extension to provide feedback from farmers, researchers' work can lose much of its relevance (Shaner et al, 1982). The competent extension agent will usually use a combination of two or more channels, which may give him a better opportunity to impact knowledge, make it more appealing and increase motivation of both farmers and researchers. Hence what extension agent needs for effective communication of agricultural technologies based on both basic and adoptive research is the crux of this study.

The general objective of this study was to identify the communication needs of extension agents in Ondo State, Nigeria. The specific objectives were to: examine the personal characteristics of extension agents; identify their perceived communication needs; ascertain how frequently extension agents receive training on communication; and identify factors to constraint communication. A null hypothesis formulated for the study is there is no significant relationship between personal characteristics of respondent and perceived communication needs

\section{Methodology}

The state has two agricultural zones namely, Owo and Ondo zones with eight and 10 blocks respectively. Both blocks have a total of 110 extension agents, and 18 block extension agents. Also Fadama project in the state has 40 facilitators, and 18 block extension agents. 50\% of the extension agents and $30 \%$ of block extensions were randomly selected for the study. Hence 75 extension agents and 5 block extension agents gave a total of 80 respondents selected for the study. A well structured questionnaire validated by expert judgement was used to gather data from the respondents. Frequency of training received by the respondents was measured in a 4 point rating scale of frequently (every 3 months) coded 4, sometimes (every 6 months) coded 3 , rarely (once a year) coded 2, and not at all code 1 . A mean score of 2.50 and above was taken to mean that respondents received training regularly on a particular area of communication needs. Perceived importance of areas of communication needs was also measured in a 4-point rating scale of very important coded 4; important code 3 , fairly important code 2 and not important coded 1 . A mean score of 2.50 and above was translated that a particular areas of communication needs was important. Communication needs constraints of respondents was measured on a 6-point rating scale of very serious coded 5 , serious coded 4 , fairly serious coded 3 , not a problem coded 2, and undecided coded 1. A mean score of 3.0 and above was taken that a particular constraint was serious. Data were analysed using percentage and mean statistic. Hypothesis was tested with Pearson Product Moment Correlation.

\section{Socio-Economic Characteristics of respondents}

\section{Results and Discussion}

Entries in Table 1 show that majority (52.5\%) of the respondents were between 41 and 50 years, it means that most of the extension agents are in their active years. This finding corroborates Fatunbi (1994) in a study of village extension workers, that majority were 44 years. Majority (58.8\%) of the respondents were 
females, agreeing with Bhatt (1998) who reported more female than male employees. Most (92.5\%) of extension agents were permanent staff implying that they will be disposed to perform their duties hence would appreciate communication needs to source proven technologies from researchers and disseminate same to farmers. This finding is similar to Ajayi (2001) who reported a higher percentage of permanent employees. All the extension workers had formal education and most (68.8\%) are HND/BSc degree holders, this education status no doubt will enhance respondents' appreciation of communication needs in agricultural extension delivery. The result agrees with Ajayi (2001) that a greater proportion of extension agents had acquired B.Agric, and or MSc qualifications. Majority (53.8\%) of the respondents have working experience of 15 years and above, an indication that they are well experienced in the job and implies that they should be able to identify important areas of communication needs. Most (93.8\%) of the respondents are extension agents this means they are field staff who would frequently relate with clients on proven technologies and practice and will therefore be knowledgeable in areas of communication needs

Table 1. Distribution of Respondents by Personal Characteristics

\begin{tabular}{|c|c|c|c|}
\hline Age (years) & Frequency & Percentage & Mean \\
\hline$>30$ & 4 & 8.0 & \\
\hline $31-40$ & 32 & 40.0 & \\
\hline $41-50$ & 42 & 52.5 & 39 \\
\hline$>60$ & 2 & 2.5 & \\
\hline Total & 80 & 100.0 & \\
\hline \multicolumn{4}{|l|}{ Gender } \\
\hline Male & 33 & 41.2 & \\
\hline Female & 47 & 58.8 & \\
\hline Total & 80 & 100.0 & \\
\hline \multicolumn{4}{|l|}{ Working status } \\
\hline Permanent staff & 74.00 & 92.5 & \\
\hline Temporary staff & 6 & 7.5 & \\
\hline Total & 80 & 100.0 & \\
\hline \multicolumn{4}{|c|}{ Educational qualification } \\
\hline Post graduate & 6 & 7.5 & \\
\hline B.Sc/HND & 55 & 68.8 & \\
\hline OND & 18 & 22.5 & \\
\hline JSS/SSCE & 1 & 1.2 & \\
\hline Total & 80 & 100.0 & \\
\hline \multicolumn{4}{|l|}{ Years of experience } \\
\hline $1-5$ & 4 & 5.0 & \\
\hline $6-10$ & 24 & 30.0 & \\
\hline $11-15$ & 43 & 5.3 .8 & 10 \\
\hline$>15$ & 9 & 11.2 & \\
\hline Total & 80 & 100.0 & \\
\hline \multicolumn{4}{|l|}{ Rank/position } \\
\hline Block extension agent & 75 & 93.8 & \\
\hline Extension agents & 5 & 6.2 & \\
\hline Total & 80 & 100.0 & \\
\hline \multicolumn{4}{|l|}{ Grade level } \\
\hline 10 & 15 & 18.8 & \\
\hline 12 & 21 & 26.3 & \\
\hline 13 & 16 & 20.0 & \\
\hline 14 & 14 & 17.3 & \\
\hline 15 & 7 & 8.8 & \\
\hline 16 & 7 & 8.8 & \\
\hline Total & 80 & 100.0 & \\
\hline
\end{tabular}

Source Field survey data

\section{Respondents' Frequency of Training}

Table 2 shows the frequency of respondents' training in the different areas of perceived communication needs. For technical needs, training was more frequent on internet website (M 3.64) followed by GSM phones with internet access $(\mathrm{M}=3.45)$, operational communication linkage $(\mathrm{M}=3.29)$ laptop $(\mathrm{M}=3.28)$, seminar $(\mathrm{M}=3.08)$ and $\mathrm{E}-\mathrm{mail}$ address $(\mathrm{M}=2.96)$. This means that training was mainly focused on modern ICTs; this might be as a result of the present trend in communication through modern ICTs which are wireless information handling tools UNDP et al (2001). The fact that training on the ICTs were frequent should be as a result of its usefulness as asserted by CTA (2003) that the potentials of ICTs in agricultural extension and agricultural development in Nigeria would only be realized if agricultural extension service adopts the use of modern ICTs in their day-to-day operations. For communicative interaction needs, support organizational development and capacity binding $(\mathrm{M}=3.41)$ and rural sociology $(\mathrm{M}=3.34)$ and personal effectiveness $(\mathrm{M}=3.38)$ had the highest frequency of training. This means respondent may improve on the level of service they render to their clientele or farmers on behalf of their organization. Training on rural sociology will assist extension agents 
understand farmers better. Personal effectiveness will assist respondents improve on their skills and competences in extension service delivery. This training will help extension agents achieve understanding of basic rural life by application of systematic body of knowledge scientifically to rural society, its organization, structure, social process, basic social systems, institutions and dynamics. This result is expected as it will assist in the realization of Ondo State's ADP objectives of facilitating incremental food production for small scale farmers and promoting infrastructural development of rural areas. For information needs, frequency of training for information needs was highest with proven agricultural technologies $(M=3.27)$ and general laws governing citizens $(\mathrm{M}=3.15)$. These training will assist respondents to be versatile in agricultural technology and to conduct themselves properly and responsibly in the conduct of communication to farmers. Other frequent training areas were sustainable environment $(\mathrm{M}=3.02)$, home economics $(\mathrm{M}=3.00)$, information on other discipline $(\mathrm{M}=2.79)$, and climate change $(\mathrm{M}=2.55)$.

\section{Respondents' Perceived Communication Needs}

Table 2 showed that internet website $(\mathrm{M}=2.81)$ was the most desirable communication need of the respondents. Others were GSM (phones with internet access (M 2.74), operational communication Linkage (M $=2.57)$ laptop $(\mathrm{M}=2.52)$ and seminars $(\mathrm{M}=2.51)$ Respondents may have desired the above communication needs as a result of willingness to seek technological information on research findings from online access. For communicative interaction needs, only extension teaching methods/process $(\mathrm{M}=2.54)$ and supporting organizational development on capacity building $(M=2.54)$ were desired by the respondents. The implication is that extension agents may desire the best methods of teaching as they are likely to reach clientele of different socio-economic groups with proven technologies and thereby seek appropriate methods for different categories of farmers e.g. different age brackets, scale of farming and individual situation of farmers. It is evident from the result that respondent did not perceived any of the information needs desirable for communication, showing that these information are already available to them, for instance proven agricultural technologies $(\mathrm{M}=2.46)$. This result agrees with the finding of Omokhudu (1999) that valuable research results have been obtained from most of the agricultural research institutes in Nigeria; and Swanson (1984) that evolution of extension begins as sufficient research knowledge is accumulated to permit effective production education programmes to keep farmers abreast of the new technologies.

Table 2 Distribution of Respondents by Frequency of Training and Perceived Communication Needs

\begin{tabular}{|c|c|c|c|c|}
\hline \multirow[t]{2}{*}{ Communication Needs } & \multicolumn{2}{|c|}{ Frequency of training } & \multicolumn{2}{|c|}{$\begin{array}{l}\text { Perceived } \\
\text { Communication } \\
\text { Needs }\end{array}$} \\
\hline & Mean & SD & Mean & SD \\
\hline \multicolumn{5}{|l|}{ TECHNICAL NEEDS } \\
\hline Internet website & $3.64 *$ & 0.557 & $2.81 * *$ & 0.506 \\
\hline GSM/phones with internet access & $3.45^{*}$ & 1.078 & $2.74 * *$ & 0.670 \\
\hline Operational communication linkage & $3.29 *$ & 0.830 & $2.57 * *$ & 0.776 \\
\hline Laptop & $3.28 *$ & 1.169 & $2.52 * *$ & 0.871 \\
\hline Seminars & $3.08 *$ & 1.111 & $2.51 * *$ & 0.914 \\
\hline Email address & $2.96^{*}$ & 0.538 & 2.21 & 1.052 \\
\hline $\mathrm{Cd}+\mathrm{rom}$ & $2.92 *$ & 0.978 & 2.41 & 1.121 \\
\hline Workshop & $2.82 *$ & 1.230 & 2.36 & 1.034 \\
\hline Radio/TV airtime with stations & 2.49 & 1.222 & 2.21 & 1.064 \\
\hline Chatroom & 2.44 & 1.210 & 2.40 & 1.121 \\
\hline Journals & 2.23 & 1.340 & 2.31 & 1.086 \\
\hline Bulletins & 2.09 & 1.285 & 2.14 & 1.076 \\
\hline Newspapers & 2.09 & 1.171 & 2.26 & 1.052 \\
\hline $\begin{array}{l}\text { COMMUNICATIVE INTERVENTION } \\
\text { NEEDS }\end{array}$ & & & & \\
\hline Rural sociology & $3.34 *$ & 0.856 & 2.18 & 0.868 \\
\hline Community development & $3.29 *$ & 0.860 & 2.31 & 0.936 \\
\hline Mass communication & $3.19 *$ & 0.995 & 2.45 & 0.884 \\
\hline $\begin{array}{l}\text { Organizing farmers association through } \\
\text { cooperatives }\end{array}$ & $3.13 *$ & 1.129 & 2.37 & 0.973 \\
\hline Use and competence in computers & $3.02 *$ & 1.067 & 2.42 & 0.839 \\
\hline Extension teaching methods/process & 2.46 & 1.292 & $2.54 * *$ & 0.913 \\
\hline $\begin{array}{l}\text { Supporting organization development on } \\
\text { capacity building }\end{array}$ & $3.41 *$ & 0.867 & $2.54 * *$ & 0.856 \\
\hline Personal effectiveness & $3.38 *$ & 0.848 & 1.95 & 0.953 \\
\hline Facilitating farmer-farmer communication & $3.29 *$ & 0.830 & 1.94 & 0.932 \\
\hline Adversary communication & $3.00 *$ & 0.886 & 1.86 & 0.910 \\
\hline Process of technologies innovation & $2.80 *$ & 1.247 & 1.80 & 0.960 \\
\hline Conflict management & 1.63 & 0.644 & 1.28 & 0.93 \\
\hline
\end{tabular}


Identifcation Of Communcation Needs Of Extension Agents In Ondo State Nigeria.

\begin{tabular}{|c|c|c|c|c|}
\hline INFORMATION NEEDS & & & & \\
\hline Proven agric technologies & $3.27 *$ & 1.006 & 2.49 & 0.871 \\
\hline General laws governing citizens & $3.15 *$ & 0.901 & 2.22 & 0.871 \\
\hline Sustainable environment & $3.02 *$ & 0.968 & 2.35 & 0.901 \\
\hline Home economics & $3.00 *$ & 0.871 & 1.95 & 0.855 \\
\hline Information on other discipline & $2.79 *$ & 0.964 & 2.15 & 0.901 \\
\hline Climate change & $2.55^{*}$ & 0.810 & 2.17 & 0.911 \\
\hline Marketing and export prices & 2.19 & 1.313 & 2.36 & 0.971 \\
\hline
\end{tabular}

\section{Communication Constraints of Respondents}

Table 3 shows the constraints to respondents' communication. Inadequate funds for proper communication $(\mathrm{M}=4.33)$ was the most serious constraint, followed by infrastructure e.g. roads $(\mathrm{M}=4.26)$. Inadequate materials for demonstration $(\mathrm{M}=3.56)$. Inadequate training programme was not a problem $(\mathrm{M}=$ 1.80) this can be explained by the fact that the respondents were frequently exposed to training (table 2 )

Table 3 Respondents Constraints to Communication

\begin{tabular}{lll}
\hline Constraints & Mean & SD \\
\hline Inadequate fund for proper communication & $4.33^{*}$ & 0.99 \\
Infrastructure-Access Roads & $4.26^{*}$ & 0.91 \\
Inadequate material for Demonstration & $3.56^{*}$ & 1.12 \\
Inadequate training programme & 1.80 & 0.89
\end{tabular}

Source: field survey data

*serious $(\mathrm{M} \geq 3.0)$

\section{Hypothesis \\ Relationship between Personal Characteristics of Respondents and their Communication Needs}

Table 4 shows that none of the variables had significant relationship with communication needs of extension agents, implying that irrespective of personal characteristics, respondents are conscious of communication needs. Age had a negative correlation $(r=-0.027)$ this means that the younger extension agents are more likely to desire communication needs than the older ones. The implication is that younger people are more willing to accept technological changes e.g. internet website, GSM/phones with internet access, laptops, Email address, CD-ROM, Radio and television airtime with stations etc as technical need than the older ones. This is in agreement with the assertion of Bertolim (2006) that older people are limited in the use of ICTs by their assumed lower income and social interaction. Working status in this research means permanent or temporary staff. The negative correlation $(r=-0.083)$ indicates that temporary staff are more likely to desire communication needs. A possible explanation for this situation is that temporary staff would thrive for perfection on the job so that they can be elevated to permanent status, as temporary status is likely to be a probation period on the job. The positive correlation $(\mathrm{r}=.027)$ for present rank/position means that extension agents with higher rank/position (blocks extension agents) will desire communication needs more than the cell/communities extension agents. A possible explanation is that extension agents with higher ranks have more communication administration responsibilities than those with lower ranks. The positive correlation $(r=0.029)$ for education means that extension agents with higher education will desire communication needs more than the extension agents with low educational qualification meaning that extension agents with higher education needs more communication skills than those with low education. The positive correlation $(r=0.027)$ for sex means that the female needs more communication skills than the male. This means that female extension agents require more communication ability to enable them communicate effectively to the female farmers because according to Onugu (2002) in principle, female workers interact with only female farmers while male workers interact with male farmers. The negative correlation $(r=-0.013)$ with working experience means that the extension agents with short time working experience need more of communication than the extension agents with long time working experiences. This implies that extension agents with short years of working experience desire more communication needs to ensure they meet the required communication skills need from them by the farmers, as those with fewer years of working experience are more of cell extension agent i.e. starting from the bottom position. The negative correlation $(r=0.150)$ with grade level means that the extension agents with lower Grade level desire more communication needs that the extension agents with higher grade. The implication of these means that extension agents with low grade level need communication skills to help them work hard enough to achieve promotion to higher levels

Table 4 Relationship between personal characteristics of respondents and their communication needs (correlations)

\begin{tabular}{lll}
\hline Variables & Pearson correlation (r) & Probability levels (p) \\
\hline Age & -0.027 & 0.811 \\
Working status & -0.083 & 0.464 \\
Present Rank/Position & 0.027 & 0.811
\end{tabular}


Identifcation Of Communcation Needs Of Extension Agents In Ondo State Nigeria.

\begin{tabular}{ccc}
\hline Education & & \\
Gender & 0.029 & 0.798 \\
Working Experience & 0.096 & 0.395 \\
Grade level & -0.013 & 0.906 \\
\cline { 2 - 3 } Source: Computed from field survey data & -0.150 & 0.185 \\
\hline
\end{tabular}

Source: Computed from field survey data

* Significant at 0.05 level (5\%)

\section{Conclusion}

From findings, the study concludes that extension agents in Ondo State ADP desire communication needs with frequency of training highest on internet website, supporting organization development on capacity building, and proven agricultural technologies, in technical, communicative interaction and information needs respectively. Extension teaching methods/process and supporting organizational development on capacity building was perceived as most important communicative interaction needs. The respondents were majorly constrained by inadequate fund for proper communication, access roads and inadequate materials for demonstration.

\section{Recommendations}

The Ondo State ADP should focus on areas where training of extension agents are presently not frequent i.e. radio/TV airtime with stations, chatroom, journals, bulletin and newspapers, extension teaching methods/ process and conflict management.

Special funds should be made available as endowments for extension agent to check the constraint of inadequate fund for communication. This can take the form of incentive to encourage them in areas of E-mail address, seminars and workshop attendance to address their areas of technical and communicative interaction needs

The Ondo State ADP should organize regular seminars and workshops to education extension agents of technical, communication interaction which they presently do not perceived can influence their communication with both researchers and farmers

The Ondo State ADP and Ministry of Agriculture should operate a realistic calendar for providing materials for demonstration prior to extension agents' visit to farmers

The Ondo State ADP in corroboration with local government authorities should provide and maintain access roads to rural areas and farming communities for reaching farmers to actualize their responsibilities of reaching farmers with proven agricultural technologies and practice.

\section{Acknowledgement}

The contribution of Miss Busayo Rosaline Adeyeye in collection of some useful information for this work is hereby acknowledged.

\section{References}

[1]. Ayayi, A.R (2001); Evaluation of extension Agents Jacob Case study of Enugu State Agriculture Development project, Nigeria journal of International Agriculture Extension Education. Vol.8, Number 3, pp 21-28.

[2]. Bertolini, R. (2006). Measuring access and use of ICTs on household level: Concept and Empirical Aspects. The centre for Development Research, Bonn Germany P.11r. bertolini@uni-bonn,de.

[3]. Bhatt, O.J. (1992) A study of socio-personal variables and job satisfaction of LTC Employees, Sauras htre University, Raijkot, p.34

[4]. CTA (2003). ICTS-Transforming Agricultural Extension? An e-discussion. Proceedings of ACT's $6^{\text {th }}$ consultative expert meeting ICTs-transforming agricultural extension? Engelhard R. (Ed.) Wageningen, 23-25 September 2003. Pp.2,6.

[5]. Fatunbi, I.T. (1994) Training Needs of village Extension Workers Under unified agricultural Extension Services in Osun State Agricultural Development of program. A research project development of Agricultural Extension, University of Nigeria Nsukka, pp.6-7.

[6]. FMARD (1976) Multi State Agricultural Development Projects (MS ADP-1) Staff Appraisal Report (SAR) World Bank Federal Agriculture Coordinating Unit (FACU)

[7]. Johnson, D.W and Johnson F.P.(1991) Joining Together: Group Theory and Group Skills, New Jersey, Prentice-Hall, $4^{\text {th }}$ Edition, p105

[8]. Lukhele, P.K. (1994) Issues and problems currently facing the agricultural sector in Swaziland with Emphasis on agricultural extension. Mimeo.

[9]. Shaner, W.W. and Philip, P.F. (1992): Farming Systems Research and Development: Guideline for Developing Countries, Westviwe Press, Boulder, Colorado, U.S.A.

[10]. Swanson, B.E. (ed) (1984): Agricultural Extension: A Reference Manual (Second Edition). F.A.O. Rome, Italy

[11]. United Nation Development Programme (UNDP) (2001). Human Development Report. Htt://www.undp.org/hdr2001./

[12]. Van den Ban, A.W and Hawkins, H.S. (1996): Agricultural Extension, Blackwell Science limited, London, p293

[13]. World Bank (1990): "Agricultural Extension: The Next Steps". Policy and Research Series of 13. Agricultural and Natural, Resources Development. Washington D.C Processed. 